DOI: https://doi.org/10.32839/2304-5809/2019-5-69-5

UDC 656.347 .8

Khodurska Mariana, Shevcheko Yuliia

National Aviation University

\title{
CONNECTION BETWEEN FINANCIAL CONDITION OF AN AIRLINE AND FLIGHT SAFETY
}

Summary. When compiling this article, the emphasis was placed on the analysis of Ukrainian legislation on air safety and comparing it to European regulations, identifying opportunities and ways to improve. The connection between the financial condition of the airline and flight safety, as well as articles about the good reputation of the airline have been investigated. It is proposed to improve Article 7 "Proof of good repute" of Regulation (EC) No 1008/2008, using a comparative analysis between road and aviation law. It was also recommended to add to the draft law of Ukraine an article about good reputation about the peculiarities of state regulation of aviation carriers' activities. Other proposed improvements include the addition of five new criteria to the Ukrainian legislation on access to air routes.

Keywords: financial condition, good repute, operating licence, flight safety, risk mitigation, preventative measures, access to routes, financial standings.

Ходурська М.Є., Шевченко Ю.В.

Національний авіаційний університет

\section{ЗВ’ЯЗОК МІЖ ФІНАНСОВИМ СТАНОМ АВІАКОМПАНІЇ ТА БЕЗПЕКОЮ ПОЛЬОТІВ}

Анотація. Складаючи цю статтю, акцент був зроблений на аналізі українського законодавства щодо безпеки повітряного руху і порівнянні його з европейськими нормативними актами, а також виявлення можливостей і шляхів їх поліпшення. Насамперед, у статті висвітлено простежений зв'язок між фрінансовим станом авіакомпанії та безпекою польотів, оцінені на досліджені ризики із якими стикається авіакомпанія, а саме: стихійні лиха, виробничі ризики та фрінансові ризики. Одним із найголовніших пунктів у законі про авіаційний транспорт ми вважаемо статтю «Про добру репутацію», тому у дослідженні було запропоновано вдосконалити Статтю 7 «Про добру репутацію» Регламенту (СС) № 1008/2008, використовуючи порівняльний аналіз між дорожнім та авіаційним законодавством Європейського Союзу. Дорожній сектор є одним з найбільш лібералізованих секторів у Свропі. Стаття 6 Постанови №1071 / 2009 від 21 жовтня 2009 року, в якій зазначаються вимоги до оператора автомобільного транспорту, перераховує умови, що стосуються доброї репутації. Було вирішено порівняти статті про добру репутації як дорожнього, так і повітряного транспорту, оскільки правила дорожнього транспорту були визнані більш повними та точними. Також було рекомендовано внести до законопроекту України статтю про добру репутацію та про особливості державного регулювання діяльності авіаційних перевізників. Інші запропоновані вдосконалення включають додавання п'яти нових критеріїв до українського законодавства щодо доступу до повітряних маршрутів, таких як тесту для підтвердження доброї репутації, наявність системи управління втомою, достатній рівень кадрового забезпечення з метою задоволення права на відпустку на робочому місці (24 дні) відповідно до Закону України про відпустки, система звітності з авіаційної безпеки та підтвердження льотної придатності судна.

Ключові слова: фінансовий стан, добра репутація, ліцензія на експлуатацію, безпека польотів, зниження ризиків, запобіжні заходи, доступ до повітряних маршрутів, платоспроможність.

Formulation of the problem. EU guidelines impact Ukrainian laws and make changes to the current laws compulsory. A draft law of Ukraine about peculiarities of state regulation of aviation carriers' activity connected with transportation of passengers and/or cargo by is based on Regulation (EC) 1008/2008 articles about working permit, financial conditions for granting operating licence, air administrator declaration, legitimacy of a working permit, suspension and denial of working permit, and all of these standards are very similar to the European one.

Recent research and publications analysis. This research is based mostly on Ukrainian and EU legislation, such as Regulation No 1008/2008, Regulation No 1071/2009, Order No. 684, Law No. 1775-III, Order No. 134, Order No 686. However, there are some researches, whose scientific publications were taken into account: Reason J., Finger M., Holvad T., Peter M. Madsen, Deephouse, D.L.

Identification of previously unsettled parts of the general problem. Given the presence of authoritative advances from the chosen topic, it should be noticed that a portion of the laws are debatable with respect to their culmination, and various significant perspectives should be improved. Due with this decision of research subject and its objective direction are adequately significant.

The purpose of the article. The main purpose is to define the connection between financial condition of an airline and flight safety and represent the ways of improvement to the Ukrainian air legislation in accordance with Common Aviation Area Agreement, as well as to identify the good repute requirements for an airline. As flight safety is an important criteria for receiving access to routes the purpose is to propose an additional qualifying points to the access to routes legislation.

Main material presentation. Recognizing the potential link between the financial health of the air carrier and safety, it is necessary to strengthen monitoring of air carriers financial status. In order to ensure proper monitoring of compliance with the operating license requirements of all Community air carriers, licensing authorities should carry out regular assessments of the financial situation of air 
carriers [2]. For checking financial conditions for granting operating licence the competent licensing authority assesses whether the enterprise applying for the first time can at any time meet its potential obligations during the 24-month period from the commencement of operation and can also cover fixed and operational costs during the first three months without taking into account any profit from its activity. For this assessment each applicant must provide a business plan for at least first three years of the business. The business plan must contain a detailed description of the applicant's financial connection with any other commercial activity in which the applicant is involved directly or through the relevant enterprises. The rules in the Regulation rules do not apply to an enterprise applying for an operating license for the operation of aircraft with a maximum take-off weight of less than 10 tones and / or with a passenger capacity of less than 20 seats.

Risk assessment and insurance. While operating, an airline may face the following risks: natural disasters, state political, industrial, commer- cial, financial. The most significant types of risks are accidents, involving flights. In Ukraine airlines have to insure these categories of risks (it is mandatory for insurance in accordance with the requirements of the Cabinet of Ministers of Ukraine dated 12.10.2012 No 1535). Types of risks in aviation industry and their mitigation are listed below:

It has been proved that there is a link between airline safety and the financial performance of the country in which an airline is based/registered/regulated. There is a stronger link to airline safety from being based in a country with strong law enforcement, higher GDP per capita and better economic growth compared to just an airline's profitability.

Analysis of proof of good repute legislation. The Article 7 Proof of good repute of Regulations $1008 / 2008$ states that for the issuance of an operating license, it must be shown that persons, who will continuously and effectively manage the business have a good reputation and are not declared bankrupt. One of the most important aspects of safety and well-functioning of an organization, in our case an airline or an aviation enterprise, is being of a good

\section{Natural disasters}

Table 1

Source/conditions of occurrence: nature and climate conditions.

\section{Forecast and impact assessment}

Preventive measures

of an aircraft, passengers, crew and cargo as a result of a natural disaster.

1.2. Damage or destruction in the air of an aircraft, passengers, crew and cargo as a result of a natural disaster.

Source: developed by the author - control by the aircraft commander and the flight crew for meteorological information on weather conditions. meteorological information on weather conditions; against falling into the zone of natural phenomena; - periodic flying training on special courses and simulators.

- compulsory insurance of an aircraft, passengers, cargo and third parties;

- compulsory insurance of an aircraft, passengers, cargo and third parties and control by the aircraft commander and the flight crew for

- periodic removals from the airship on the precautionary measures

Table 2

\section{Production risks}

Source/conditions of occurrence: disasters and incidents involving an aircraft, fires, explosions and other phenomena associated with the operation of the aircraft's technical mechanisms, which have caused damage to the aircraft and people.

\section{Forecast and impact assessment}

2.1. Damage or destruction on the ground of an aircraft, passengers, crew and cargo as a result of destruction as a result of selfbreakdown of an aircraft.

2.2. Damage or destruction in the air of an aircraft, passengers, crew and cargo as a result of self-breakdown of an aircraft.

2.3. Damage or destruction on the ground of an aircraft, passengers, crew and cargo as a result of destruction as a result of not qualified actions.

2.4. Damage or destruction of an aircraft, passengers, crew and cargo on the ground or in the air, as a result of airplane incidents on the ground due to the fault of the airport.

\section{Preventive measures}

- compulsory insurance of an aircraft, passengers, cargo and third parties;

- provision of constant control of the aircraft technical condition on the part of the engineering aviation service in accordance with the normative documents on the technical inspection of the aircraft.

- compulsory insurance of an aircraft, passengers, cargo and third parties;

- provision of constant control of the aircraft technical condition on the part of the engineering aviation service in accordance with the normative documents on the technical inspection of the aircraft;

- ensuring constant control over the level of knowledge and skills of the crew on actions in cases of failure of the material part in flight; - periodic flying training on special courses and simulators.

- compulsory insurance of an aircraft, passengers, cargo and third parties;

- ensuring constant control over the level of knowledge and skills of the crew on actions in cases of failure of the material part in flight; - periodic flying training on special courses and simulators.

- compulsory insurance of an aircraft, passengers, cargo and third parties;

- provided in the agreement with the airports of the item with the full responsibility of the airport in case of an accident or incident; - instructing its own staff to ensure the reception and release of the aircraft for the care of airfield security. 
Financial risks

Source/conditions of occurrence: the financial risks include all factors that deteriorate the financial condition of the enterprise: socio-political risks, risks associated with the peculiarities of public administration and rising prices in the fuel supply market and aircraft maintenance components; competitive risks; etc.

\begin{tabular}{|l|l|}
\hline \multicolumn{1}{c|}{$\begin{array}{c}\text { Forecast and impact } \\
\text { assessment }\end{array}$} & \multicolumn{1}{c|}{ Preventive measures } \\
\hline 3.1. Socio-political risks & $\begin{array}{l}\text { When performing work outside the territory of the base, it is necessary to study } \\
\text { the social circumstances in the region in which the flights are performed in order } \\
\text { to make a decision on the development of preventive countermeasures to the main } \\
\text { social threats, taking into account: the criminalization level of the region, the zone } \\
\text { of national conflicts, the sphere of influence of criminal groups and others. }\end{array}$ \\
\hline $\begin{array}{l}\text { 3.2. Risks associated with } \\
\text { the peculiarities of public } \\
\text { administration in the regions }\end{array}$ & $\begin{array}{l}\text { It is necessary to study the peculiarities of state governance in the regions with the } \\
\text { aim of reducing the inefficient expenditures of financial resources. To avoid risks, it } \\
\text { is necessary to study information on the regulatory framework governing aviation. }\end{array}$ \\
\hline 3.3. Competitive risks & $\begin{array}{l}\text { Analyzing the information on the economic performance of other enterprises in } \\
\text { this area, it is necessary to consider the possibility of the emergence in the market } \\
\text { of competitors that will offer similar services at lower prices or better quality. } \\
\text { The use of aircraft with low cost of operation and advanced technology of data } \\
\text { collection and processing allows customers to offer competitive high-quality } \\
\text { service at the lowest price. }\end{array}$ \\
\hline
\end{tabular}

Source: developed by the author

repute. Good repute has to be proved by the owner, top rank managers and the organization as a whole. Reputation may arise from the perception and appreciation of the organization by stakeholders, and can be considered an important value because it affects the organization's ability to receive resources. A good repute can also result in the customer giving the company the "benefit of the doubt" when experiencing uncertainty in a crisis [7]. This relies upon how solid the relationship is between the association and the partners and how much the partners have put resources into the relationship. In the event that partner connections are not solid before the emergency, those partners that are hurt by the emergency or bolster those gatherings hurt by the emergency will pull back their help and conceivably compound or draw out the emergency circumstance.

Road sector is one of the most liberalized sectors in Europe [8]. Article 6 of Regulation 1071/2009 dated 21 October 2009, which states the requirements for becoming road transport operator, lists the conditions relating to the requirement of good repute. It has been decided to compare the articles regarding good repute of both road and air transport legislation, as the rules in road transportation regulations were found more complete and precise. After analyzing the various details in road transportation Regulation we recommend adding some provisions to the Regulation 1008/2008 to improve evidence of good reputation, including:

1. working time and rest period for cabin crew and pilots;

2. excessive and incorrect loading of an aircraft;

3. delays and regularity of aircraft movements;

4. violation of national rules in the fields of commercial law;

5. violations in the area of pay and employment conditions.

Access to routes Law improvement. Order No 686 dated 13 November 2014 on Aviation Rules of Ukraine "Procedure for granting and cancellation of rights to operate air routes" states a way of choosing the airline that will operate on a certain route. If State Aviation Administration of Ukraine has received applications from two or more air car- riers for the same route, the corresponding right is granted to the air carrier, which received more points according to the criteria. The following formula is used for calculation of points:

\section{Pparticipant $=M \times$ Iparticipant $\div$ Iwinner}

where $\mathrm{M}$ - number of points (maximum); $\mathrm{P}$ - number of participant's points (except for the winner according to the relevant criteria); $I_{\text {partici- }}$ pant - participant's indicator according to the relevant criteria; $I_{\text {winner }}$ - indicator of the winner according to the relevant criteria.

The result is rounded to one hundredth and are added. Criteria, which should be taken into account by the Commission, is represented in the Table 4 .

After analyzing the criteria already provided in the Law, it has been decided that some improvements would be useful to consider. The proposed criteria are represented in Table 5.

Firstly, it is advised to add proof of fit-and-proper-person, which can also be called a proof of good repute. Fit-and-proper-person test or director's test is a test aiming to prevent corrupt or untrustworthy businessmen from serving on the board of certain organizations. To be a fit and proper person to engage in aviation activities means that the person: is competent to operate an aviation business (as demonstrated by the person's knowledge, skills and experience); has the attributes of good character, diligence, honesty, integrity and judgment; is not disqualified by law from performing their role in an aviation business; either has no conflict of interest in performing their role in an aviation business, or any conflict that exists will not create a material risk that the person will fail to properly perform their role in an aviation business; not bankrupt now or in the past; is not involved and has not been involved in an airline business that has been prosecuted for criminal breaches of Ukrainian aviation and workplace law; has never provided false or misleading information to regulating authorities or made a willfully false or misleading statement; whether the public is likely to have confidence in the person's suitability to be involved in an organization that provides commercial passenger and freight 
Criteria for granting rights to operate on an air route

\begin{tabular}{|l|c|}
\hline \multicolumn{1}{|c|}{ Criteria } & $\begin{array}{c}\text { Number } \\
\text { of points } \\
\text { (maximum) }\end{array}$ \\
\hline $\begin{array}{l}\text { Actual use by the air carrier of the previously granted rights to operate the air routes (the ratio of } \\
\text { frequencies of performed flights to the total number of frequencies on which the air carrier has been } \\
\text { granted the rights to operate). }\end{array}$ & 10 \\
\hline $\begin{array}{l}\text { The amount of money paid to the State Budget of Ukraine for the last 12 consecutive months } \\
\text { preceding the month in which the application was filed, per one aircraft. }\end{array}$ & 10 \\
\hline $\begin{array}{l}\text { The number of aviation incidents and accidents per one million flights that the air carrier is required to } \\
\text { report to the State Aviation Service during the last 12 consecutive months preceding the filing date (the } \\
\text { lower the coefficient, the higher the score). If the air carrier does not have a flight safety management } \\
\text { system and the procedure for conducting internal investigations and / or analysis of events and / or } \\
\text { there is no flight statistics, according to this criterion, such air carrier receives 0 points. }\end{array}$ & 10 \\
\hline $\begin{array}{l}\text { Regularity of flights performed during the last 6 months preceding the day of filing an application } \\
\text { (percentage of flights performed without delays from the total number of flights for the specified period). }\end{array}$ & 10 \\
\hline
\end{tabular}

Source: developed by the author according to the data [5]

Table 5

Proposed criteria for improvements of Order No 686 dated 13 November 2014

\begin{tabular}{|l|c|}
\hline \multicolumn{1}{|c|}{ New criterion } & Number of points (maximum) \\
\hline Fit-and-proper-person test/ Proof of good repute & 10 \\
\hline Evidence of a fatigue management system & 10 \\
\hline $\begin{array}{l}\text { Sufficient staffing levels in order to meet workplace leave entitlements } \\
\text { (of 24 days) under Law of Ukraine about vacations }\end{array}$ & 10 \\
\hline Aviation Safety Reporting System & 10 \\
\hline Proof of Airworthiness & 10 \\
\hline
\end{tabular}

Source: developed by the author

air transportation; any other relevant matter. To demonstrate that the person has these attributes, he/she will need to: identify the people involved in the management; specify which of those people the owner will rely on to demonstrate that the company is competent to engage in aviation activities; provide the responsible authority with information about each of those people, their role in aviation business and their past conduct, and, if they will be responsible managers, their knowledge and experience. In deciding whether an applicant for a licence is a fit and proper person to hold the licence, the Ukrainian aviation regulating authority must only take into account: any action taken by the Ukrainian aviation regulating authority, or a responsible organization, in relation to any authority to perform duties essential to the operation of an aircraft during flight time that was given to the applicant by the Ukrainian aviation regulating authority, or the organization; and any other matter that relates to the safety of air navigation. For evaluation of fit and proper person only two variants of points can be used, and they are 10 or 0 . There are no middle points because the person is either fit-and-proper or not.

The second recommendation is the requirement that the applicant (airline) provide evidence of a fatigue management system. Fatigue management refers to the ways in which airline providers manage their safety and fatigue. ICAO has a performance-based approach, which is required by the state-approved FRMS implementation service provider. The number of points given should be regulated by the independent party, which evaluates fatigue management quality.

The third recommendation is to improve Order No. 686 that establishes the requirement for the airline to prove through the business plan that the applicant will manage a viable business with a sufficient staffing level to meet the regulatory requirements of the minimum aviation crew and have a sufficient minimum staffing level in order to meet the work leave entitlement place of Ukraine (24 days) in accordance with the Law of Ukraine on Holidays.

The fourth advice would be to check Aviation Safety Reporting System as voluntary reporting is a world-wide used system and very well known for improving safety and preventing new aviation incidents or accident.

The last but not the least recommendation is proving airworthiness of an aircraft. EASA uses a definition in Basic Regulations (EC) No 216/2008, Article 5 Airworthiness: each aircraft shall be issued with an individual certificate of airworthiness when it is shown that it conforms to the type design approved in its type-certificate and that relevant documentation, inspections and tests demonstrate that the aircraft is in condition for safe operation. The independent audit maintenance records to certify airworthiness of the applicant airlines' fleet are proposed. The certification should be independent as is not reliable if done by the employees of the airline, but not third party. The level of airworthiness should be measured in percentage and then transformed into 0 to 10 points, where $100 \%$ is a maximum of 10 points.

Conclusions and suggestions. Based on everything mentioned in the report a conclusion that Ukrainian legislation has to be improved and brought to the level of EU regulations can be made. A draft law of Ukraine about peculiarities of state regulation of aviation carriers' activity connected with transportation of passengers and/or cargo by air is based on European common rules for the operation of air services is a good start but is still a project. 
It has been proved the financial standings of an airline influence the flight safety, therefore must be checked by responsible governmental, as well as independent authorities. As an outcome of market opening, travel opportunities for EU and Ukrainian passengers would improve and there would be economic advantages for EU and Ukrainian airlines and airports. Ensuring that that the opening and the integration of the markets is undertaken in a balanced manner is crucial. In this context, it will be necessary to ensure that the process of market opening is accompanied by a parallel process of regulatory co-operation and gradual convergence. This is particularly important in critical areas such as safety, security, environmental protection and application of competition law.

\section{References:}

1. Draft Common Aviation Area Agreement between the European Union and its member states and Ukraine.

2. Regulation (EC) No 1008/2008 of the European Parliament and of the Council of 24 September 2008 on common rules for the operation of air services in the Community.

3. Council Regulation (EEC) No 3922/91 of 16 December 1991 on the harmonization of technical requirements and administrative procedures in the field of civil aviation.

4. Order No 134 dated 10 March 2017 "License terms regarding transportation of passengers, dangerous goods and dangerous goods waste on air transport".

5. Order No 686 dated 13 November 2014 on Aviation Rules of Ukraine "Procedure for granting and cancellation of rights to operate air lines".

6. Regulation (EC) No 1071/2009 of the European Parliament and of the Council of 21 October 2009 establishing common rules concerning the conditions to be complied with to pursue the occupation of road transport operator and repealing Council Directive 96/26/EC.

7. Deephouse D.L. and Carter S.M. "An Examination of Differences Between Organizational Legitimacy and Organizational Reputation”, Journal of Management Studies, 2005. Pp. 329-360.

8. Finger M., Holvad T. Regulating Transport in Europe. 2013. 264 p. 